\title{
Correction: Invitation to Progress in Earth and Planetary Science
}

\author{
Yasufumi Iryu ${ }^{1,2}$
}

\section{Correction}

The original published version of this article (Iryu 2014) did not include details of Professor Yasufumi Iryu's affiliation with the JpGU (Japan Geoscience Union). The full author affiliation details are as follows:

1. JpGU (Japan Geoscience Union), 2-4-16 Yayoi, Bunkyo-ku, Tokyo 113-0032, Japan

2. Institute of Geology and Paleontology, Graduate School of Science, Tohoku University, Aobayama, Sendai 980-8578, Japan.

Received: 2 June 2014 Accepted: 2 June 2014

Published: 27 June 2014

\section{Reference}

Iryu Y (2014) Invitation to progress in earth and planetary science. Prog Earth Planet Sci 1:2

Cite this article as: Iryu: Correction: Invitation to Progress in Earth and

Planetary Science. Progress in Earth and Planetary Science 2014 1:12

${ }^{2}$ Institute of Geology and Paleontology, Graduate School of Science, Tohoku University, Aobayama, Sendai 980-8578, Japan

Submit your manuscript to a SpringerOpen ${ }^{\circ}$ journal and benefit from:

- Convenient online submission

- Rigorous peer review

- Immediate publication on acceptance

- Open access: articles freely available online

- High visibility within the field

- Retaining the copyright to your article

Submit your next manuscript at $>$ springeropen.com

\section{空}

(c) 2014 Iryu; licensee Springer. This is an Open Access article distributed under the terms of the Creative Commons Attribution License (http://creativecommons.org/licenses/by/4.0), which permits unrestricted use, distribution, and reproduction in any medium, provided the original work is properly credited. 